NBSIR 83-2677

\title{
Analysis of Electrical Fire Investigations in Ten Cities
}

U.S. DEPARTMENT OF COMMERCE

National Bureau of Standards

National Engineering Laboratory

Center for Fire Research

Washington, DC 20234

March 1983

Interim Report

Sponsored by:

Consumer Product Safety Commission

5401 Westbard Avenue

Bethesda, MD 20016 



\section{ANALYSIS OF ELECTRICAL FIRE INVESTIGATIONS IN TEN CITIES}

Alan Gomberg and John R. Hall, Jr.

U.S. DEPARTMENT OF COMMERCE

National Bureau of Standards

National Engineering Laboratory

Center for Fire Research

Washington, DC 20234

March 1983

Interim Report

Sponsored by:

Consumer Product Safety Commission

5401 Westbard Avenue

Bethesda, MD 20016

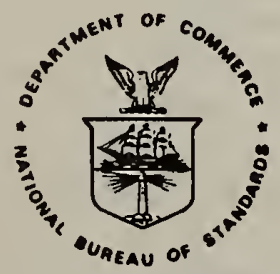

U.S. DEPARTMENT OF COMMERCE, Malcolm Baldrige, Secretary NATIONAL BUREAU OF STANDARDS, Ernest Ambler, Director 

List of Figures.................................... v

List of Tables...................................... vi

Abstract $\quad \ldots \ldots \ldots \ldots \ldots \ldots \ldots \ldots \ldots \ldots \ldots \ldots \ldots \ldots \ldots \ldots \ldots \ldots \ldots \ldots \ldots \ldots \ldots$

1. INTRODUCTION................................... 1

2. DESCRIPTION OF WORK............................ 3

3. OVERVIEW OF CHARACTERISTICS OF FIRE INCIDENTS............. 4

3.1 Fixed Property Use.............................. 5

3.2 Area of Origin..................................... 5

3.3 Equipment Involved in Ignition and Form of Heat of Ignition. ...................................... 6

3.4 Detector Performance............................... 8

3.5 Extent of Flame Damage........................... 8

3.6 Time of Fire................................. 8

3.7 0ccupant Condition................................ 9

3.8 Comparison with National Fire Data................. 9

4. OVERVIEW OF ELECTRICAL SYSTEMS $\ldots \ldots \ldots \ldots \ldots \ldots \ldots \ldots \ldots \ldots \ldots \ldots \ldots \ldots$

4.1 Electrical Component Involved in Ignition............. 12

4.2 Alterations to Building Electrical System.............. 12

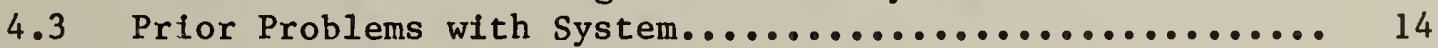

4.4 Fire Occurrence at Splice or Connection................ 15

4.5 Recent Alterations to Component Involved in Ignition..... 16

4.6 Panel Board Location, Shelter from the Elements and Ambient Conditions.............................. 17

4.7 Wiring Method, Material and Size.................... 17

4.8 Specific Component Failure Causing the Fire........... 18

5. CHARACTERISTICS AND PERFORMANCE OF OVERCURRENT PROTECTION

DEVICES....................................... 22

5.1 Performance of the Overcurrent Protection Devices....... 22

5.2 Overcurrent Protection Devices by Component

Involved in Ignition........................... 28

5.3 Overcurrent Protection Device Rating by Minimum Wire

Size of Branch Circuit.......................... 28

6. THE ROLE OF BUILDING AGE......................... 33

6.1 Edison Base Fuses and Circuit Breakers by Age of Building.................................. 34

6.2 System Alterations by Age of Building............... 36

6.3 Components Involved in Ignition by Age of Bullding...... 37

6.4 Wiring Method by Age of Building.................. 37

6.5 Separate Grounding Conductor.................... 40 
7. THERMAL INSULATION.............................. 40

8. SERVICE COMPONENT FIRES.......................... 41

9. BRANCH CIRCUIT WIRING FIRES....................... 41

10. CORD AND PLUG FIRES............................. 42

11. SWITCHES, OUTLETS AND RECEPTACLES.................. 44

11.1 Age of Building and Overcurrent Protection Devices...... 45

11.2 Problems with Splices and Connections............... 45

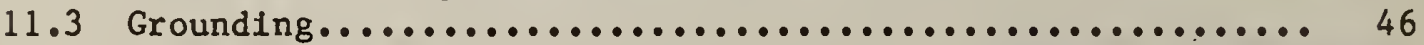

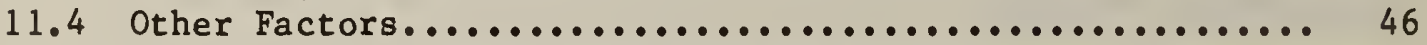

12. LIGHT FIXTURE, LAMPHOLDER AND PORTABLE LAMP FIRES .......... 47

13. CONCLUSIONS..................................... 47

14. ACKNOWLEDGEMENTS................................ 48

15. REFERENCES...................................... 49 


\section{LIST OF FICURES}

Page

Flgure 1. Performance of Overcurrent Protection Devices, by Type of Device and with Reference to the Presence or Absence of Tampering and Unusual Panel Conditions........

Figure 2. Tampertng by Year Built and Type of Overcurrent

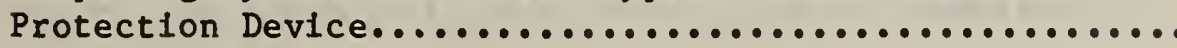


$\underline{\text { Page }}$

Table 1. Electrical Fire Cases by City..................... 2

Table 2. Area of Origin.............................. 6

Table 3. Equipment Involved in Ignition vs. Form of Heat of Ignition................................ 7

Table 4. Time of Fire and Component Involved in Ignition......... 9

Table 5. Fixed Property Use Comparison...................... 10

Table 6. Equipment Involved in Ignition Comparison............. 10

Table 7. Extent of Flame Damage Comparison................... 11

Table 8. Electrical Component Involved in Ignition............. 13

Table 9. Summary of Prior Problems....................... 15

Table 10. Percent of Fire Involving Splices, Connections or Termination for Each Component Involved in Ignition...... 16

Table 11. Percent of Fires Involving Recent Alterations to Component Involved in Ignition..................... 16

Table 12. Percentage of System Alterations for Each Wiring Method.. 18

Table 13. Wiring Method and Component Involved in Ignition........ 19

Table 14. Branch Circuit Conductor Wire Sizes (A.W.G.).......... 20

Table 15. Fa1lure Mode by Component........................ 21

Table 16. Type of Overcurrent Protection Device................ 22

Table 17. Incidence of Unusual Conditions Found at Panel......... 24

Table 18. Miscellaneous Characteristics for Fires Where Circult Breakers Were Present...........................

Table 19. Overcurrent Protection Devices for Each Component Involved in Ignition..........................

Table 20. Wire Size and Overcurrent Protection Device Rating by Type of Device..............................

Table 21. Overcurrent Protection Device Performance by Type and Rating of Device and Wire Size - Percentage of Cases Where Device Interrupted Current................ 
Table 22. Ratio of Electrical Fires to Housing Untts by Age of Housing...................................

Table 23. Ratios of Fire Rates for Post-1940 and Pre-1940

Housing by Type of Component Involved in Ignition....... 38

Table 24. Wiring Method by Bullding Age and Type of Overcurrent Protection Device............................. 39

Table 25. Detalls of Improper Location of Extension Cords......... 44 
$s$ 
Analysis of Electrical Fire Investigations in Ten Cities

Alan Gomberg and John R. Hall, Jr.

National Bureau of Standards

Washington, D.C. 20234

This interim report describes the progress and conclusions to date on an analysis of electrical fire cases by the Center for Fire Research, Nattonal Bureau of Standards for the Consumer Product Safety Commission. The report describes the 110 detalled electrical fire Investigation reports from 10 particlpating cities, and discusses preliminary findings resulting from analysis of the computerized data from those reports. These preliminary findings include factors which may cause overcurrent devices to fail to operate, the role of extensiton cords misused as permanent extensions of building wiring, and the problems of loose connecthons between receptacles and wirlng. They are being used to guide a follow-on effort, to be reported on at a later date, to obtain, encode and analyze additional data from the original 110 cases. This second effort will better define and describe the most significant fallure modes of electrical components and the sequences of events that lead to electrical fire ignition.

\section{INTRODUCTION}

This report describes characteristics and patterns of 110 electrical fires, with special attention to those patterns that suggest hypotheses on ftre prevention programs and product design. Data for this initial analysis were collected in 10 cities, as shown in table 1. The Consumer Product Safety Commission (CPSC) sponsored the research and suggested an initial set of issues to be examined. The U.S. Fire Administration (USFA) and its consultant, John Ricketts, collected the data and implemented a training program on the identification of electrical fires for fire department personnel in these 10 cities. The resulting detatled electrical fire investigation cases were provided to the Center for Fire Research ( $C F R$ ) for review, coding and analysis. All electrical fires Investigated occurred during the period of March 1980 through December 1981, but the actual period of data collection varied from city to city. 
City

Akron, Ohio

Grand Rapids, Michigan

Long Beach, California

Oakland, California

Portland, Oregon

Sacramento, California

San Diego, Callfornia

San Francisco, California

San Jose, California

Toledo, Ohio
No. of Cases

22

4

9

1

11

15

7

17

11

$\frac{13}{110}$

NOTE: An additional four cases were provided but could not be included in the analysis because of Incomplete documentation and Inadequate detail.

The intent of this initial analysis is to formulate questions and hypotheses, where possible, regarding the nature of significant electrical fatlures, the electrical distribution components involved in fire origination, and the identification of the mechanisms resulting in component failure. The results will be used to direct efforts at further isolating and understanding electrical fire problems and possible remedial actions. The small number of cases avallable, the wide variety of electrical fallure modes and limitation. In the Initlal coding, permit only this kind of exploratory analysis. The questions raised and the hypotheses brought forth by this interim report will direct the coding of additional data in the existing and additional cases, leading to identification of the key electrical fallure modes producing fires and finally to research on possible corrective actions. As a first step, addittonal coding and analysis of the existing cases are being performed as a followup to this interim report and will be documented in a final project report. 


\section{DESCRIPTION OF WORK}

The detailed investigations used a fire incident report and a two part questionnalre with one part contalning general information on the electrical system and the second part containing detailed information on the electrical component involved. The questionnaire is not reproduced here due to its length. Coples may be obtained from Linda Smith, Consumer Product Safety Commission, Division of Hazard Analysis/Epidemiology, 5401 Westbard Avenue, Bethesda, MD 20016. In addition, most of the cases included photographs and detailed electricians reports, including schematics of the buildings' electrical systems and other relevant details. Approximately one-third of the cases also contalned samples of the damaged components.

The detailed investigations were made based on preliminary field determination of electrical origin by the responding fire company and subsequent confirmation by fire investigators. After the completion of each investigation the completed questionnalres, photographs and samples were sent to the USFA consultant Mr. Ricketts, who reviewed them and contacted the investigators as necessary to clear up questions and problems. The completed cases were then passed on to CFR, through CPSC, for coding and analysis.

The coding was screened by personnel skilled in electrical engineering, according to the following procedure: The principal investigator coded each case, using the investigator reports, photographs and physical samples where available. The points on which he felt further input was needed were identified. An NBS electrical engineer then provided the needed input. (This procedure of input only as deemed necessary was first tested on a random sample of ten cases, with the electrical engineer reviewing all coding, not just items where input was requested.) Input from the electrical engineer proved necessary in approximately one-third of the cases.

The computer coding was set up according to a three-part format which also roughly corresponds to the organization of the material in this report. First, the incident report data were coded using the data elements and 
conventions employed in the National Fire Incident Report System (NFIRS) $[1]^{1}$. (Most citles included incident reports prepared for NFIRS or using a simflar format.) Analyses of this information are contained in section 3 of this report. Second were the general descriptions of electrical systems, based on Part 1 of the questionnalre. Analyses of this information are contained In section 4 of this report. Third were the detalled descriptions of the partlcular electrical components involved in the fires. Analyses of patterns for each major type of component are contained in sections 8 through 12 of this report. Sections 5 through 7 of this report deal with 1 ssues that need to be examined both relative to all components and relative to each major type of component Involved in Ignition. These lssues are characterlstics and performance of overcurrent protection devices, the role of bullding age, and the role of thermal insulation.

\section{OVERVIEW OF CHARACTERISTICS OF FIRE INCIDENTS}

This section presents some mafor patterns based on tabulations of key Incldent Report parameters. Subsequent sections present an overview of some electrical report information and more detalled examinations of fallure modes and key characteristics and present significant findings and hypotheses.

Following are brlef definitions of the Incident Report parameters examined.

Fixed Property Use - The type of property that the fire occurred in.

Area of Origin - The room or space where the fire originated.

Detector Performance - The presence or absence of smoke detector( 8 ) and their functioning.

Extent of Flame Damage - The final extent of flame and heat damage due to the fire.

$\overline{l_{\text {Numbers }} \text { in brackets }}$ refer to the literature references listed at the end of this paper. 
Time of Fire - Usually the time (often shortly after Ignition) that the flre was reported to the fire department.

Occupant Condition - A description of the occupancy of the structure just prior to the fire (all occupants asleep, at least one occupant awake, etc.).

Equipment Involved in Ignition - The equipment which provided the heat which started the fire (fixed wiring, cord, plug, etc.).

Form of Heat of Ignition - The form of the heat energy igniting the fire (water caused arc, arc from mechantcal damage, etc.).

\subsection{Fixed Property Use}

Most cases ( $84 \%$ ) were single family dwellings, with the remainder either duplexes $(9 \%)$ or small apartments (up to $\operatorname{six}$ units) (7\%). By design, no fires in large apartment complexes (containing over six units) were investigated. This distribution compares well with national Census estimates of occupied housing units for 1978, which indicate that 84 percent of the occupied housing that contains four or fewer individual units are single unt and 16 percent are structures contatning two to four dwelling units [2]. In other words, there was no indication that some types of housing, within this. 1imited set; were more prone to electrical fires than others.

\subsection{Area of Origin}

The area of fire origin was coded in NFIRS format. The results are tabulated in table 2. Concealed spaces - within ceiling, walls and attics were the leading Areas of Origin, totaling 43 percent of all fires. Only 34 percent of the fires started in normally occupied living areas (living rooms, bedrooms, etc.). 
Area

Bedroom
Living Room
Basement
Kitchen
Carage
Dining Room
Closet
Concealed Space - Wall
Concealed Space - Attic
Exterior Wall Surface
Concealed Space - Celling
Crawl Space
Other

Total
Percent of Total

$17.3 \%$

$7.3 \%$

$7.3 \%$

$7.3 \%$

$4.5 \%$

$1.8 \%$

$0.9 \%$

$21.8 \%$

$15.5 \%$

$7.3 \%$

$5.5 \%$

$0.9 \%$

$2.6 \%$

As would be expected, the majority (72\%) of branch circuit wiring fires occurred in concealed spaces. In addition, $60 \%$ of the fires involving receptacles were in concealed spaces. Together these two components accounted for $74 \%$ of the concealed space fires. For fires in living areas, the dominance of bedroom fires is accounted for by cords and plugs, which were involved in $68 \%$ of the bedroom fires. Almost half (46\%) of the cord, plug fires in the data base occurred in bedrooms.

\subsection{Equipment Involved in Ignition and Form of Heat of Ignition}

These data elements are compared in table 3.

Several combinations of Equipment Involved and Form of Heat stand out in table 3. Loose and faulty connections (35\%) are the leading known Form of Heat for fixed wiring, although mechanical damage (24\%), defective or worn insulation ( $18 \%$ ) and overloaded equipment $(18 \%)$ are well represented. Loose and faulty connections (64\%) also dominate the Equipment Involved category of switch, receptacle, outlet. The cord and plug Equipment Involved category is dominated by mechanical damage $(50 \%)$ and overloaded equipment (33\%). 


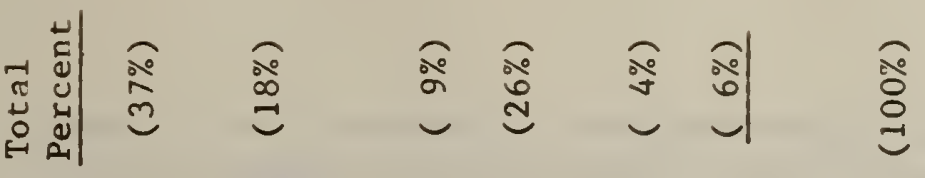

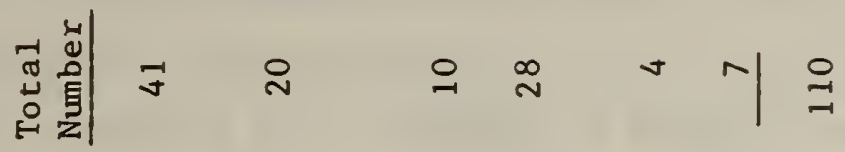

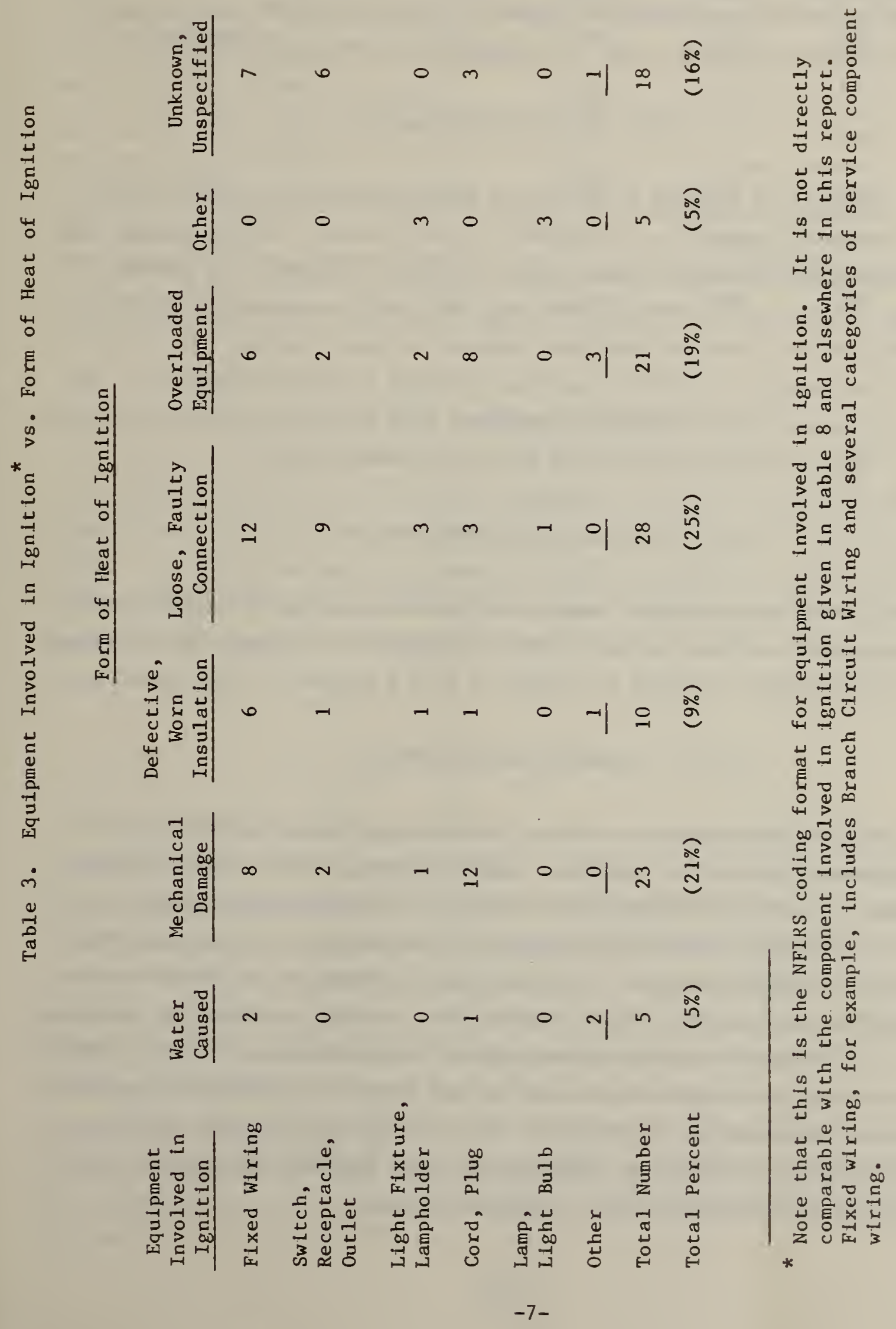


The other equipment categories have no dominant Form of Heat. Further analysis of sone of these patterns, using the more detalled data in the Part 1 and Part 2 reports, can be found in the subsequent sections, whlch address the primary electrical components involved in ignition. The breakdown of this more detalled data is not directly comparable with the NFIRS type coding for equipment involved, however, due to differences in the coding formats.

\subsection{Detector Performance}

The presence or absence of detectors was established in 95 of the 110 cases. They were present in 14 percent of the 95 cases. This compares with the 1980 national estimates, which shows detectors present in 20 percent of all flres in one- and two-family dwellings and small apartments. The fact that detectors are known to have been present in about one-half of all households in the country in 1980 [3] and were present in only 14 percent of the fires in this data base indicates that homes with smoke detectors may be less likely to have a reported electrical fire than homes without.

\subsection{Extent of Flame Damage}

The final extent of flame damage was known in all but two cases, and flame damage was confined to the object of origin in 41 percent of the cases. Flames spread beyond the room of origin in only 8 percent of the cases.

\subsection{Time of Fire}

As table 4 indicates, the time of fire is distributed differently for each component involved in ignition. Some patterns, such as light fixture fires occurring predominantly in the 6:00 p.m. to midnight timeframe, are expected, but others, including the frequent occurrence of receptacle/outlet fires in the morning hours and of branch clrcult fires in the afternoon and evening hours, are not so readily explainable. Initial attempts at examining these distributlons have not produced promising hypotheses. Further attempts will be made to understand the factors behind these time distributions, such as examining detalled causal patterns and obtaining typical load profiles of residential power consumption. Comparisons with national estimates on time distribution of electrical fires will also be made. 
Table 4. Time of Fire and Component Involved in Ignition

\begin{tabular}{lccccc}
\hline & $\begin{array}{c}\text { Midnight } \\
-6 \text { a.m. }\end{array}$ & $\begin{array}{c}6 \text { a.m. } \\
\text { Noon }\end{array}$ & $\begin{array}{c}\text { Noon } \\
6 \text { p.m. }\end{array}$ & $\begin{array}{c}6 \text { p.m. } \\
\text { M.dnight }\end{array}$ & $\begin{array}{c}\text { All } \\
\text { Hours }\end{array}$ \\
\hline Service Components & $20 \%$ & $20 \%$ & $27 \%$ & $33 \%$ & $14 \%$ \\
\hline Branch Circuit Wiring & $13 \%$ & $16 \%$ & $34 \%$ & $38 \%$ & $29 \%$ \\
\hline Receptacles and Outlets & $21 \%$ & $36 \%$ & $25 \%$ & $18 \%$ & $26 \%$ \\
\hline Cords and Plugs & $15 \%$ & $15 \%$ & $35 \%$ & $35 \%$ & $18 \%$ \\
\hline Light Fixtures & $14 \%$ & $7 \%$ & $29 \%$ & $50 \%$ & $13 \%$ \\
\hline All Components & $17 \%$ & $20 \%$ & $30 \%$ & $33 \%$ & $100 \%$ \\
\hline
\end{tabular}

\subsection{Occupant Condition}

Occupant Condition at the time of ignition, while not an NFIRS data element, was included on the incident report, and was known in 85 of the 110 cases. In 69 percent of these cases at least one occupant of the dwelling was awake and alert at the time of ignition. All occupants were asleep or impaired in 14 percent of the cases, and no one was home in 17 percent of the cases.

\subsection{Comparison with National Fire Data}

National fire cause distributions can be estimated from data in the National Fire Incident Reporting System (NFIRS), which contains computerized fire incident reports on fire causes and fire losses from over 30 states. An attempt was made to compare the distributions of several key elements with national estimates calculated from the NFIRS. Cood correlation between national estimates and the study data was noted for the elements Fixed Property Use, Detector Presence and Equipment Involved in Ignition. Substantial differences were noted for the element Extent of Flame Damage. Finally, substantial differences found in two other key elements, Area of Origin and Form of Material Ignited, are believed to be due to differences in the application of the coding methodology. A discussion of each element follows. 
Fixed Property Use in the study data base was divided Into three categorles, single family dwellings (excluding moblle homes), duplexes and small apartments (up to six units). The distribution of Fixed Property Use in the study data base was compared with the estimated national distribution of similar categortes from NFIRS, and the results are lllustrated in table 5 . No major differences between the two data bases are noted.

Table 5. Fixed Property Use Comparison

F1xed Property Use

Stngle Family

Duplex

Apartment (up to six units) $\underline{\text { CPSC }}$

$83.5 \%$

$9.2 \%$

$7.3 \%$
National Estimate

$88.5 \%$

$5.0 \%$

$6.5 \%$

Equipment Involved in Ignition, as indicated in table 6 (with unknowns excluded) did not show large variances between the study data base and national estimates. The nine Equipment Involved categories were generally in the same proportions for both, and thetr rank order is the same. This indicates that the electrical components studied in detall here are represented in a simflar manner to their relative national distribution as estimated from NFIRS.

Table 6. Equipment Involved In Ignition Compartson

\begin{tabular}{|c|c|c|c|c|}
\hline Equipment & CPSC & Rank & $\begin{array}{l}\text { Nat lonal } \\
\text { Est Imate } \\
\end{array}$ & Rank \\
\hline Fixed Wiring & $37.3 \%$ & 1 & $39.3 \%$ & 1 \\
\hline Cord, Plug & $25.4 \%$ & 2 & $18.6 \%$ & 2 \\
\hline Switch, Receptacle, Outlet & $18.2 \%$ & 3 & $11.8 \%$ & 3 \\
\hline Lighting Fixture, Lampholder & $9.1 \%$ & 4 & $11.5 \%$ & 4 \\
\hline Lamp, Light Bulb & $3.6 \%$ & 5 & $6.9 \%$ & 5 \\
\hline Overcurrent Protection Device & $2.8 \%$ & 6 & $5.5 \%$ & 6 \\
\hline Other & $1.8 \%$ & 7 & $3.5 \%$ & 7 \\
\hline Meter & $0.9 \%$ & 8 & $\frac{1.5 \%}{100}$ & 8 \\
\hline Total & $100.0 \%$ & & $100.0 \%$ & \\
\hline
\end{tabular}

As noted in section 3.4, Detector Presence was compared for the study data and national estimates and was found to be similar. 
A substantial difference between national estimates and study data was noted when Extent of Flame Damage was compared, as Indicated by table 7 .

Table 7. Extent of Flame Damage Comparison

\begin{tabular}{|c|c|c|c|c|}
\hline \multirow[b]{2}{*}{ Extent of Flame Damage } & \multirow[b]{2}{*}{ CPSC } & \multicolumn{3}{|c|}{ National } \\
\hline & & Rank & Est1mates & Rank \\
\hline Object & $41.1 \%$ & 1 & $31.5 \%$ & 1 \\
\hline Part Room & $35.5 \%$ & 2 & $19.8 \%$ & 4 \\
\hline Room & $15.0 \%$ & 3 & $19.9 \%$ & 3 \\
\hline Floor & $6.5 \%$ & 4 & $5.9 \%$ & 5 \\
\hline Building & $0.9 \%$ & 5 & $20.9 \%$ & 2 \\
\hline Outside Building & $0.9 \%$ & 5 & $2.1 \%$ & 6 \\
\hline
\end{tabular}

It is obvious from both the percentage distributions and the rankings of Extent of Flame Damage that the study data base tends toward the smaller fire much more than those in the NFIRS. This may be an artifact of the case selection process. In this study, emphasis was placed on detalled investigation, and larger fires may not have been considered as the extensive destruction of the site often precludes detailed investigation. On the other hand, all fires are supposed to be reported to NFIRS. This suggests that property loss figures from this study cannot be directly compared with national estimates.

The relatively high proportion (69 percent) of cases where occupants were awake and alert at ignition may also account in part for the relatively low level of fire damage in the subject cases.

Significant discrepancies between the study data and national estimates were found when Area of Origin and Form of Material Ignited were compared. They are believed to be artifacts of the coding procedure, however, resulting from a combination of more detailed and thorough investigation and analysis of the study cases than is usual for the fire incidents in NFIRS, and the resulting ability to use a more exacting application of the coding procedures in the study cases. 


\section{OVERVIEW OF ELECTRICAL SYSTEMS}

This section contains overview Information from the detailed electrical fire Investigation reports. Subsequent sections present more detalled information on selected parameters. These parameters are discussed separately from the incident report elements because, in some cases, simllar parameters coded separately in the two reports are not directly comparable.

\subsection{Electrical Component Involved in Ignition}

Table 8 shows the Components Involved in Ignitlon for the 110 cases.

The first four categorles (15 incldents) refer to utility system components tied to the particular bullding; they are usually located between the bullding's final overcurrent protection device and those utility system components not tied to a particular bullding. The four categorles are referred to collectively as service components. In general, analysis of service components was done on the group as a whole, as the limited number of fires involving each individual component precluded more detalled analysis even at an exploratory level.

Of the remaining components, branch circuits provided the most cases, with nonmetallic sheathed cable and knob and tube dominating. Cords and plugs, in particular extension cords, contributed significantly to the total. Receptacles and outlets dominated their category, as did incandescent 11ghting. Some light fixture incidents were not electrical system breakdowns but were due to combustibles placed too close to otherwise normally operating lighting equipment; this will be discussed further in subsequent sections.

\subsection{Alterations to Building Electrical System}

Overall, 72 percent of the electrical systems in this study had been altered to some extent prior to the fire. These alterations ranged from minor (such as extension of a circult) to major replacement or modification of system components. Some were system upgrades, such as replacement of deteriorated wiring or modernizing and upgrading system capacity, while others, such 
Table 8. Electrical Component Involved In Ignition

Component

Utility Supply Conductors Overhead Utility WIres

Service Entrance Wiring Service Entrance Cable Service Entrance Conductors in Conduit Meter, Meter Box, Meter Mounting

Service Equipment

Service Entrance Conductor Termination Grounding Electrode Conductor Service Disconnect

Distribution Panel Feeder Wiring

Branch Circuit Wiring Armored Cable (BX) Nonmetallic Sheathed Cable (Romex) Knob and Tube Multiple Types

Cords and Plugs

Extension Cord

Cord on Appliance

Cord on Portable Lamp

Christmas Tree Wiring

Plug Adapter

Cord-Heating Device

Switch, Receptacle, Outlet Wall Type Switch

Receptacle, Outlet

Baseboard Heater Thermostat

Lighting Fixture, Lampholder Fluorescent Lighting Fixture Incandescent Lighting Fixture Lampholder Portable Lamp
No. of Incidents

$\underline{3}$

$\underline{7}$

4

2

1

4

1

2

1

$\underline{1}$

32

16

9

2

28

15

8

2

1

1

1

20

18

1

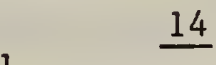

7

3

3

Low Voltage Transformer Low Voltage Transformer 
as addition of bootleg circults, splicing improper wiring into circults, or bypassing overcurrent protection devices had the effect of downgrading the system. More than half of the alterations had been made less than 5 years before the flire.

The relationship of system alterations to varlous fire attributes is discussed in subsequent sections. There is no information in the currently coded data, however, on the relevance of the alterations to the fire, including specific nature and extent of the alterations performed. In particular the characterization of alterations as improvements or downgrades was not coded for this initial analysis, although the information needed to make those determinations was often collected. The addition of selected factors relating to system alterations will be done in the followup to this report, and the analyses will be documented in the project Final report.

\subsection{Prior Problems with System}

Information on any problems involving the electrical system prior to the fire incident was recorded by the investigator through discussion with the butlding occupant. Some problems were noted immediately prior to (or simultaneous with) the ignition, while other problems appear to have occurred over extended pertods of time.

Information on the presence or absence of prior problems was obtained in 97 percent of the cases; of these the existence of one or more prior problems was noted 44 percent of the time. Of the 47 cases with at least one prior problem, 70 percent had one, 21 percent had two, 4 percent had three, 2 percent had four, and 2 percent had five or more prtor problems. Overall, in these 47 cases, a total of 67 specific problems were noted. Of the 18 different types of problems noted, the most common manifestation of a problem was fuses blowing, followed closely by lights flickering.

The noted prtor problems undoubtedly represent a lower bound of those actually occurring, because some respondents may not have remembered or may have omitted reference to prior problems. One indication that this may be occurring is that, although fuses blowing was noted as a problem in only 18 cases, overfusing was noted in 34 cases. 
Table 9 lists the categories of prior problems noted and their frequencies. Some occurred singly, and others, as indicated earlier, occurred in comblnation.

Table 9. Summary of Prior Problems (Prior Problems Noted in $44 \%$ of the Cases)

\section{Problem Description}

Fuses Blowing

Lights Flickering

Lights Dimming

Breakers Tripping

Appliances Operating Slowly

Bulbs Burning Out Prematurely

Radio Sounding Scratchy

Sparking, Arcing at Outlet

Lights Going Out

Previous Similar Fire

Unable to Turn off Light

Smoke \& Heat at Receptacle

Hot Cord

High Electric Bills

Lights Failing to Turn On

Range Burners Burning Out

Lights Turning on and off Due to Vibration

Unspecified

\section{Number of Times Cited}

$\begin{array}{lr} & 18 \\ 15 \\ 8 \\ 6 \\ 3 \\ 3 \\ 2 \\ 2 \\ 1 \\ 1 \\ 1 \\ \\ \\ \text { Vibration } \\ 1 \\ \text { Total } & 1 \\ & 1 \\ & 1 \\ & 1 \\ & 1 \\ & 67\end{array}$

Initial efforts were made to correlate the most frequent prior problems with the component involved in ignition, but no significant results were obtained. Further efforts will be made in the followup, with special attention to grouping of similar prior problems into a smaller number of categories. This is more likely to reveal any significant correlation between prior problems and electrical failure mode if one exists. An attempt will also be made to compare prior problems with system age if that information is obtained in the followup.

\subsection{Fire Occurrence at Splice or Connection}

The fire occurred at a wire termination, connection or splice in 38 percent of the cases. Of these, 95 percent were copper wiring, and the remaining 5 percent were aluminum wiring. As indicated in table 10, receptacles and outlets were the components where fires most often occurred at a 
wire termination, connection or spllce. Also, 42 percent of the branch clrcult/splice fires involved knob and tube wiring.

Table 10. Percent of Fires Involving Splices, Connections or Termination for Each Component Involved in Ignition

Component

Service Components

Branch Clrcuit Wirlng

Cords and Plugs

Receptacles and Outlets

Light Fixtures

Transformer
Percent of Fires at Splice, Connection, Termination

$20 \%$

$40 \%$

$33 \%$

$55 \%$

$43 \%$

$0 \%$

\subsection{Recent Alterations to Component Involved in Ignition}

In 20 percent of the cases, the component involved in ignition had been recently altered, rewired, replaced or installed. (Note that this is not the same question as the alterations to system code discussed in section 4.2 . This code refers to alterations to the involved component, not to the overall electrical system.) As table 11 shows, light fixtures were most frequently found to have been recently altered, rewired, replaced or installed. This Information, combined with table 10 information that 43 percent of light fixture fires occur at splices, indicates further evaluation of characteristics of recently made splices in 1 ight fixtures is needed. This will be further addressed in a subsequent section.

Table 11. Percent of Fires Involving Recent Alterations to Component Involved in Ignition

Component

Service Components

Branch Clrcuit Wiring

Cords and Plugs

Receptacles and Outlets

Light Fixtures
Percent Recently Altered, Etc. 
Conversely, while table 10 shows that splices and connections are a major problem with receptacles and outlets, only 10 percent of the receptacle fires showed recent alterations. The indication here is that whlle splices and connections (actually these are most likely wire terminations) are a problem for receptacles and outlets, the problem may not be related to recent installation or alteration. This question will be further addressed in the followup.

4.6 Panel Board Location, Shelter from the Elements, and Ambient Conditions

The final overcurrent protection device for the branch circuit was in a panel board located on the exterfor of the building in 32 percent of the 95 fires that did not involve service components. A panel board installed in the interior of the building was provided in the other 68 percent of these cases. Fused systems were located inside the bullding slightly more of ten than circult breakers. Shelter from the elements was provided in 87 percent of the 30 cases with a panel board located on the exterlor of the building. No shelter was provided in 10 percent of the cases and in 3 percent the presence or absence of panel board shelter was unknown.

In 95 percent of the 95 fires not involving service components, the ambient conditions at the panel board were judged to be normal for the area and time of year. Two cases ( 2 percent) were judged unusually hot, and three cases ( 3 percent) were judged unusually damp.

\subsection{Wiring Method, Material and Size}

of the 95 fires not involving service components, nonmetallic-sheathed cable (type NM,"Romex") was used in 49 percent of the cases, knob and tube in 25 percent, electrical metallic tubing (EMT) and armored cable (type AC "BX") each in 6 percent, and the remaining types of wiring, including multiple types in a single circuit, in one or two cases each. Copper wiring was used in 95 percent of the cases, aluminum wirtng in 4 percent and steel wiring in 1 percent. Nonmetallic-sheathed cable was used in the steel wiring case and 3 of the 4 aluminum wiring cases; the fourth alumlnum wiring case used service entrance cable (type SE). 
Table 12 shows how the presence or absence of system alterations varles by type of wiring method.

Table 12. Percentage of System Alterations for Each Wiring Method

Wiring Method

Nonmetallic sheathed cable Knob and Tube

- Electric Metallic Tubing Armored Cable Other*

Total
Number of Cases

46

24

6

6

$\frac{13}{95}$
Percent Percent with Alterations $67 \%$

$71 \%$

$50 \%$

$100 \%$

$92 \%$

* The category "other" includes individual conductors in both rigid and flexible metal conduit, and those cases where more than one type of wiring was used within the involved circuit.

Table 13 shows the distribution of wiring method by component involved in ignition.

Table 14 shows the relative frequency of wiring sizes of the involved branch circuit conductors for all cases not involving service components, for the smallest AWG size present in the circuit (Part A) and for the various combinations found (Part B).

\subsection{Specific Component Fallure Causing the Fire}

Table 15 shows the distribution of components whose failure caused the fire by each of the major groups of components involved in ignition. For each of these 94 cases (service components and the single transformer case are excluded), the description of the component whose fallure caused the fire was provided in a narrative, and the resulting 79 types of component failure descriptions were organized into the 23 major groupings shown on the table. Several analyses have been performed using these groupings, as described in later sections, and the tabulation in table 15 provides some insights in itself. (For example, over half of the lighting fixture fires - those 
Table 13. Wiring Method and Component Involved in Ignition

\section{Percentage of Wiring Methods}

\begin{tabular}{|c|c|c|c|c|c|c|}
\hline & $\begin{array}{c}\begin{array}{c}\text { Nonmetallic } \\
\text { Sheathed } \\
\text { Cable }\end{array} \\
\end{array}$ & $\begin{array}{l}\text { Knob and } \\
\text { Tube } \\
\end{array}$ & $\begin{array}{c}\text { Armored } \\
\text { Cable }\end{array}$ & $\begin{array}{c}\text { Electric } \\
\text { Metallic } \\
\text { Tubing } \\
\end{array}$ & Other ${ }^{*}$ & $\begin{array}{c}\text { Number } \\
\text { of } \\
\text { Cases }\end{array}$ \\
\hline $\begin{array}{l}\text { Branch Ctrcuit } \\
\text { Wiring }\end{array}$ & $47 \%$ & $25 \%$ & $0 \%$ & $16 \%$ & $12 \%$ & 32 \\
\hline Cords and Plugs & $32 \%$ & $32 \%$ & $18 \%$ & $0 \%$ & $18 \%$ & 28 \\
\hline $\begin{array}{l}\text { Outlets and } \\
\text { Receptacles }\end{array}$ & $62 \%$ & $14 \%$ & $5 \%$ & $0 \%$ & $19 \%$ & 21 \\
\hline Lighting Fixtures & $64 \%$ & $29 \%$ & $0 \%$ & $7 \%$ & $0 \%$ & 14 \\
\hline
\end{tabular}

Percentage of Components Involved In Ignition

\begin{tabular}{|c|c|c|c|c|c|}
\hline & $\begin{array}{l}\text { Branch } \\
\text { Circuit } \\
\text { Wiring } \\
\end{array}$ & $\begin{array}{l}\text { Cords } \\
\text { and } \\
\text { Plugs } \\
\end{array}$ & $\begin{array}{c}\begin{array}{c}\text { Outlets } \\
\text { and }\end{array} \\
\text { Receptacles } \\
\end{array}$ & $\begin{array}{l}\text { Lighting } \\
\text { Fixtures } \\
\end{array}$ & $\begin{array}{c}\text { Number } \\
\text { of } \\
\text { Cases } \\
\end{array}$ \\
\hline $\begin{array}{l}\text { Nonmetallic sheathed } \\
\text { cable }\end{array}$ & $33 \%$ & $20 \%$ & $27 \% 20 \%$ & 46 & \\
\hline Knob and Tube & $33 \%$ & $38 \%$ & $12 \% 7 \%$ & 24 & \\
\hline Armored Cable & $0 \%$ & $83 \%$ & $17 \% 0 \%$ & 6 & 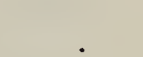 \\
\hline $\begin{array}{l}\text { Electric Metallic } \\
\text { Tubing }\end{array}$ & $83 \%$ & $0 \%$ & $0 \% 17 \%$ & 6 & \\
\hline Other* & $31 \%$ & $38 \%$ & $31 \% 0 \%$ & $13 \%$ & \\
\hline
\end{tabular}

\footnotetext{
* The category "other" includes individual conductors in both rigid and flexible metal conduit, and those cases where more than one type of wiring was used within the involved circuit.
} 
Table 14. Branch Circuit Conductor Wire Sizes (A.W.G.)

A. Wire Size Distribution (Smallest AWG Size in Circuit)

\begin{tabular}{c} 
Wire Size \\
\hline 6 \\
8 \\
10 \\
12 \\
14 \\
$16 *$ \\
$18 *$ \\
Unknown
\end{tabular}

Total

\section{Percent}

$2 \%$
$2 \%$
$2 \%$
$24 \%$
$64 \%$
$1 \%$
$1 \%$
$4 \%$
$100 \%$

B. Combinations of Wire Size

Number of Cases

6 only
8 only
10 only
12 only
14 only
10 and 8
12 and 10
14 and 12
16 and 12
18 and 14
Unknown

Total

2

2

1

22

53

1

1

7

1

1

$\frac{4}{95}$

* These cases, where smaller than normal wire was found within branch circuits, had power cord/lamp cord spliced directly into the involved branch circuit. 
Table 15. Failure Mode by Component

A. Branch Circult Wiring (34\% of Tota 1)

Mechanical damage or improper installation

(e.g., stapled, abraded, nailed, cut, other)

$9(28 \%)$

Poor or loose splice (e.g., loose splice,

crimp, different wire types)

$8(25 \%)$

Ground fault (e.g., water, ungrounded armored

cable, deteriorated insulation)

Use of improper wiring in circuit

(e.g., steel, stranded)

$3(9 \%)$

Knob and tube encapsulated

Miscellaneous overload

(e.g., overloaded, short in range)

Unknown

B. Cords and Plugs ( $30 \%$ of Total)

Mechanical damage or poor splice

(e.g., to extension cord or appliance cord)

Overloaded extension cord

$6(21 \%)$

Overloaded plug

$2(7 \%)$

Danlaged plug (e.g., loose blade connector)

$2(7 \%)$

Miscellaneous -- plug (e.g., short, water)

$2(7 \%)$

Miscellaneous -- cord (e.g., deteriorated

insulation, electric blanket cord)

$4(14 \%)$

Unknown

$1(4 \%)$

C. Receptacles and Outlets (21\% of Tota1)

Loose or poor connection

$8(40 \%)$

Mechanical damage (e.g., cracked, fire)

$3(15 \%)$

Overloaded

$2(10 \%)$

Miscellaneous (e.g., deteriorated, miswired, plug inserted improperly)

Unknown

D. Lamp and Lighting Fixtures ( $15 \%$ of Total)

Loose or poor connection or splice, miswiring

Combustibles too close (e.g., ballast, cloth

fixture, towel, insulation)

Overlamped

Miscellaneous (e.g., deteriorated insulation)

Note that the failure mode descriptions are highly dependent on the main component, that is, mechnical damage to branch circuit wiring may be of a different nature than mechanical damage to cords. 
involving overlamping or combustibles too close - do not involve fallures within the electrlcal system.) But it is also recognized that further refinement - aggregatlon, disaggregation or reaggregation - of these categories may better reflect the important similarlties in conditions. Suggestions are invited, therefore, not only with regard to additional promising analysis of fire characteristics versus component-failure scenarios but also with regard to the groupings used to organize those scenarios for analysis.

\section{CHARACTERISTICS AND PERFORMANCE OF OVERCURRENT PROTECTION DEVICES}

The distribution of cases among the different types of overcurrent protection devices are as shown in table 16. Edison-base fuses and circuit breakers dominated, and most of the analyses in this section concern only them.

Table 16. Type of Overcurrent Protection Device

Type of Device

Circuit Breakers

Edison Base Fuses

Type "S" Fuses

Cartridge Fuses

No Device Present

Not Applicable*

Unknown
Number of Fires

\section{4}

39

1

0

1

13

Total
Percent of Fires

49.1

35.5

0.9

0.0

0.9

11.8

$\frac{1.8}{100.0}$

*

In 13 of the 15 service component cases, the fire occurred outside the bullding's overcurrent protection device, and so the type of device in use may not have been relevant. In the other 2 service component cases, there were two separate outside main breaker panels and the fire occurred in the connection between them; therefore the types of devices used in these main breaker panels were relevant for those cases.

\subsection{Performance of the Overcurrent Protection Devices}

Problems with the overcurrent protection devices were checked under two headings - tampering and unusual conditions. Tampering generally referred to conditions intended to defeat the overcurrent protection device, such as overfusing (or the analogous condition for clrcuit breakers, overamping), 
putting a penny or other metal insert behind a fuse, wrapping a fuse with foll, or having no protective device at all. Unusual conditions included all the conditions covered under tampering and other problem conditions, such as exposed wiring, poor workmanship, ground cut-offs, double taps, and bootleg or jackleg circults.

Of the 39 Edison-base fuses, 15 (38\%) interrupted the current, while 18 (46\%) did not. For the remaining 6 fuses, 3 ( $8 \%$ ) operated when the circuit was interrupted by fire, and the other $3(8 \%)$ had unknown performance. of the 54 circuit breakers, $16(30 \%)$ interrupted the current, while 26 (48\%) did not. For the remaining 12 cases, 2 (4\%) operated when the circuit was damaged by fire, and the other $10(19 \%)$ had unknown performance.

Tampering and unusual conditions found at the panel were almost universal for the Edison-base fuses. Of the 39 fuses, 32 ( $82 \%$ ) were tampered with, 3 (8\%) were not, and the tampering status was unknown for the other 4 panels (10\%). Similarly, unusual conditions were noted at the panel in 35 (90\%) of the cases, while 2 (5\%) had none noted, and the other $2(5 \%)$ were unknown. Of the 32 cases of tampering, 31 (97\%) involved overfusing; the other case involved a penny behind the fuse. Two of the cases with overfusing also involved a penny behind the fuse.

By contrast, unusual conditions at the panel were not found for most circuit breakers and tampering was comparatively rare. Of the 54 circuit breakers, 5 (9\%) were tampered with, 46 (85\%) were not. The tampering status was unknown in the other $3(6 \%)$ cases. Similarly, unusual conditlons were noted in $14(26 \%)$ of the cases and were not found in 39 (72\%) of the cases. The other one ( $2 \%$ ) was unknown. All 5 cases of tampering involved overamping (i.e., overfusing of circuit breakers). In 2 of these cases the circuit breakers did automatically trip initially, but occupants reset them.

Of the 17 cases not cited as involving Edison-base fuses or circult breakers, one of the two cases with device cited as unknown was also cited as overfused and was stated to have been reset. The one case with no device was cited for tampering in that the circuit was left unprotected. Table 17 shows the type of unusual panel conditions cited. 
Table 17. Incidence of Unusual Conditions Found at Panel

(Unusual conditions were noted in $37 \%$ of the cases)

\section{Fuses}

A. Individual Conditions

Overfusing

Ground cut-off

Bootleg/jackleg circuits

Double taps

Poor workmanship

Defeated

Fused neutral
Total Number of

Conditions Cited

$\begin{array}{rr}34 & 54 \% \\ 8 & 11 \% \\ 7 & 11 \% \\ 6 & 9 \% \\ 5 & 8 \% \\ 2 & 3 \% \\ 1 & 2 \% \\ 63 & 100 \%\end{array}$

Number of Cases $\%$ of Total

15

$42 \%$

Overfusing alone

Overfusing and double taps

Overfusing and ground cut-off

Overfusing and bootleg/jackleg circults

Qverfusing and poor workmanship

Overfusing and defeating

Overfusing, double taps and bootleg/jackleg circuits

Overfusing, poor workmanship and ground cut-off

2

$11 \%$

4

$11 \%$

2

$6 \%$

1

$3 \%$

1

$3 \%$

2

$6 \%$

Overfusing, bootleg/jackleg circuits, and ground cut-off

1

$3 \%$

Overfusing, poor workmanship and bootleg/jackleg circuits

1

$3 \%$

Overfusing, poor workmanship and fused neutral

1

$3 \%$

Defeated, bootleg/jackleg circuits and ground cut-off 
A. Individual Condtions

Poor workmanship

Ground cut-off

Bootleg/jackleg clrcuits

Overamping

Double taps

Fused neutral

Defeated

Exposed wiring

B. Combinations of Conditions

Overamping alone

Poor workmanship alone

Fused neutral

Bootleg/jackleg circuits

Poor workmanship and ground cut-off

Poor workmanship and bootleg/jackleg circuits

Double taps and ground cut-off

Defeated and ground cut-off

Poor workmanship and exposed wiring

Poor workmanship, double taps and bootleg/jackleg circuits

Poor workmanship, bootleg/jackleg circults and ground cut-off
Total Number of

Conditions Cited

7

$\%$ of Total

$29 \%$

5

$21 \%$

4

$17 \%$

3

$13 \%$

2

$8 \%$

1

$4 \%$

1

$4 \%$

1

$4 \%$

24

$100 \%$

$\frac{\text { Number of Cases }}{3}$

$\%$ of Total $22 \%$

1

$7 \%$

1

$7 \%$

1

$7 \%$

2

$15 \%$

1

$7 \%$

1

$7 \%$

1

$7 \%$

1

$7 \%$

1

$7 \%$

$\frac{1}{14}$

$\frac{1}{14} \quad \frac{7 \%}{100 \%}$

\section{Other}

Unknown device: 1 with overfusing, poor workmanship and bootleg/jackleg circuits

1 with poor workmanship and bootleg/jackleg clrcuits

No device present: 1 with unprotected circuits, exposed wiring and bootleg/jackleg circuits 
Figure 1 shows the contrast in tampering and unusual panel conditions between fuses and circuit breakers and shows the impact on the performance of the devices. Both fuses and circuit breakers managed to interrupt current in some cases when they were tampered with or hampered by unusual conditions. Fuses, however, always interrupted the current in those few cases when neither of these conditions were present, but circuit breakers did not. This unusual finding regarding circuit breakers stimulated several additional analyses aimed at identifying the reasons for non-performance.

System alterations were present in the same proportion for fuses and circult breakers, and for both types of devices, interruption of current was more likely in a building that had had alterations than in one that had not. This suggests that many alterations may have constituted improvements. of the 39 fuse cases, 28 (72\%) had had alterations and the other 11 had not. In the 54 circuit breaker cases, 39 (72\%) of the electrical systems had been altered and the other 15 had not. As for performance, 11 of the 28 fuses with system alterations (39\%) interrupted the current after the ignition, compared to 4 of the 11 fuses without system alterations (36\%). Thirteen of the 39 circuit breakers with system alterations (33\%) interrupted the current after the ignition, compared to 2 of the 15 circuit breakers without system alterations $(13 \%)$. As noted earlier, further analysis of system alterations to determine their effect will be done in order to determine the relevance of this factor to this and other elements.

In summary, the pattern of performance for both major devices - circuit breakers and Edison-base fuses - shows them failing to interrupt the current in well over half the cases. For the fuses, the story is essentially one of widespread tampering, but for the circuit breakers a promising explanation has proved elusive in this initial analysis.

An attempt was made to classify the fires into cases where the overcurrent protection device should or should not have interrupted the current with the classification made on the basis of a shorthand description of the component and condition that caused the fire. This was done on the theory that many of the circuit breaker cases might have been situations where neither a fuse nor a circuit breaker would have been expected to work. This 


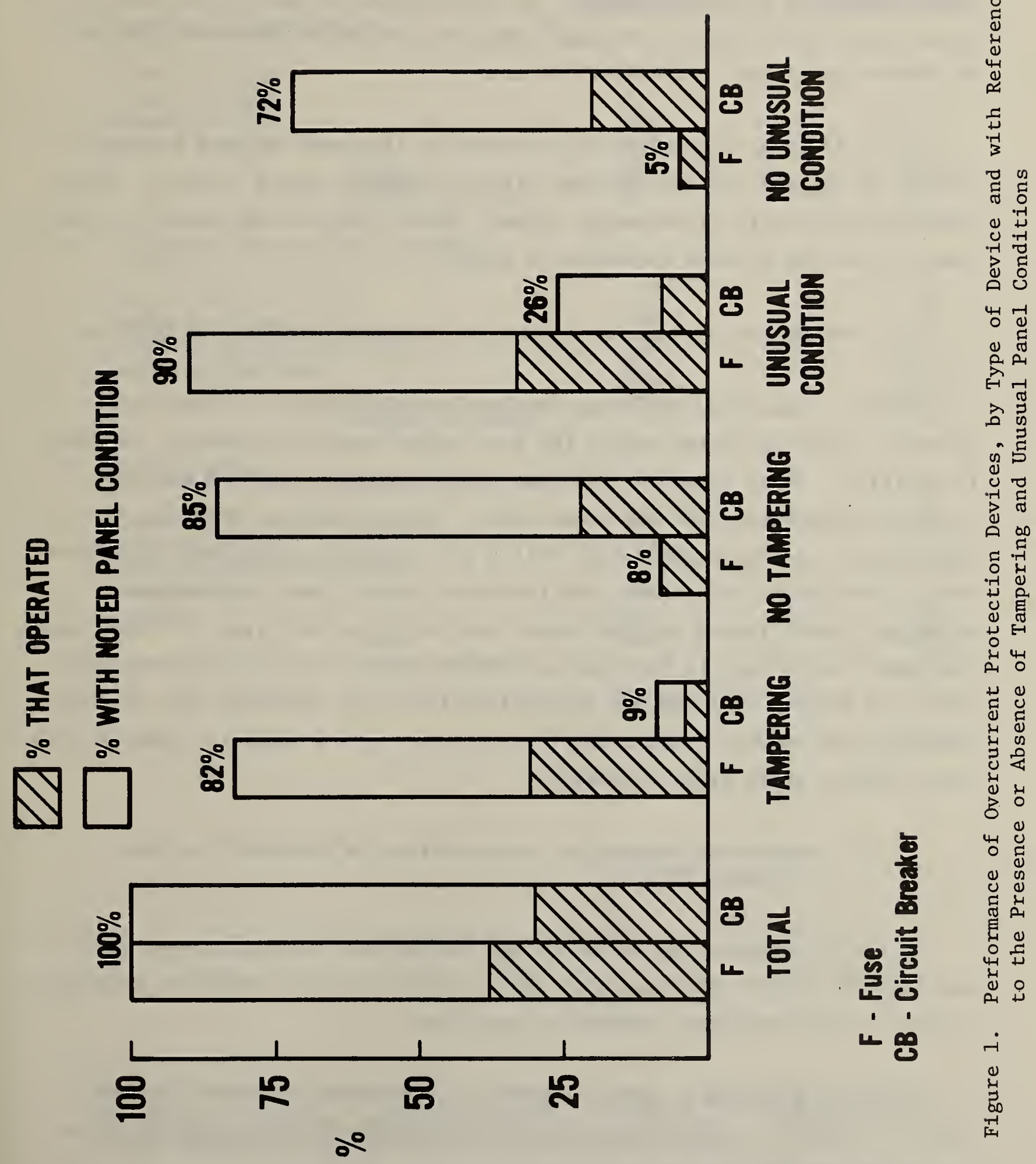


very preliminary review indicated that many fires involved circumstances where neither a fuse or a circuit breaker would have been expected to work (e.g., a towe 1 dropped on a portable lamp). An attempt will be made in the followup to better classify this factor through additional review of each case, and will be further discussed in the final report.

Table 18 shows some other characteristics that were checked for their ability to suggest reasons why some circuit breakers falled to work. These characteristics will be evaluated in more detall when the additional information on fuse and breaker operation is coded.

\subsection{Overcurrent Protection Devices by Component Involved in Ignition}

Table 19 shows how the type, problems and performance of overcurrent protection devices varied across the four major types of components involved in ignition. Fires involving switches and receptacles involved far more circuit breakers than did the other fires. This correlates with the fact (noted later in this report) that switch and receptacle fires were much more evenly distributed by building age than were other fires, and the newer buildings, which tended to have lower rates of all other types of fires, were also much less likely to have fuses. Branch circuit wiring fires were more likely in systems that had had alterations than were any other type of fire. Tampering and unusual panel conditions were noted less often in cord and plug fires than in other types of fires.

\subsection{Overcurrent Protection Device Rating by Minimum Wire Size of Branch Circuit}

Table 20 compares the rating of the overcurrent protection device to the smallest AWG size of the wire used in the branch circuit conductors supplying current to the component involved in ignition.

Table 21 provides a further examination in terms of whether the overcurrent protection device operated, given the type of device, the rating of the device and the size of the wire. 
Table 18. Miscellaneous Characteristics for Fires Where Circuit Breakers Were Present

Circuit Breakers Circuit Breakers

A. Extent of Flame Damage**

Operated * Did Not Operate*

Object of Origin

$36 \%$

Area of Origin

$14 \%$

$69 \%$

Room of Origin

$29 \%$

Beyond Room of Origin

$21 \%$

$100 \%$

Total

14

$19 \%$

$8 \%$

$\frac{4 \%}{100 \%}$

Number of Fires

26

B. Component Involved in Ignition

Branch Circuit Wiring

Cords and Plugs

Switches and Receptacles

Lighting Fixtures

Total

Number of Fires
$27 \%$

$40 \%$

$20 \%$

$13 \%$

15
$19 \%$

$31 \%$

$31 \%$

$19 \%$

26

C. Wiring Method

Nonmetallic sheathed cable

$60 \%$

$65 \%$

Knob and Tube

$7 \%$

$13 \%$

$12 \%$

Electric Metallic Tubing

Armored Cable

Other

Total

Number of Fires

$0 \%$

$12 \%$

$20 \%$

$100 \%$

15

$4 \%$

$\frac{7 \%}{100 \%}$

26

* These figures exclude service component fires. Cases where the fire damaged the circuit, causing the device to operate, or where it was not known whether the device operated, are also excluded.

**

Note that one of the cases where the circuit breaker operated had unknown
extent of ire damage. 
Table 19. Overcurrent Protection Devices for Each Component Involved in Ignition

A. Branch Clrcuit Wiring

Number of fires

Percent of fires

Percent with tampering

Percent with unusual panel conditions

Percent with system alterations

Percent where device interrupted current

\section{Edison \\ Base \\ Fuses}

16

$52 \%$

$88 \%$

$94 \%$

$81 \%$
Circuit

Breakers

15

$48 \%$

$14 \%$ (of 14)

$27 \%$

$80 \%$
Combined

31

$100 \%$

$53 \%$ (of 30$)$

$61 \%$

$81 \%$

(One case, not shown above, involved a type "S" fuse.)

B. Cords and Plugs

Number of fires

Percent of fires

Percent with tampering

Percent with unusual panel conditions

Percent with system alterations

Percent where device interrupted current

(One case, not shown above, involved a device of unknown type.)

\section{1}

\section{$41 \%$}

$88 \%$ (of 8

$90 \%$ (of 10 )

$64 \%$

$40 \%$ (of 10) 43\% (of 14)

16

$59 \%$

$0 \%$ (of 15)

$19 \%$

$19 \%$

$69 \%$

C. Switches and Receptacles

$\begin{array}{lccc}\text { Number of fires } & 4 & 15 & 19 \\ \text { Percent of fires } & 21 \% & 79 \% & 100 \% \\ \text { Percent with tampering } & 100 \% & 20 \% & 37 \% \\ \text { Percent with unusual panel conditions } & 100 \% & 33 \% & 60 \% \\ \text { Percent with system alterations } & 50 \% & 73 \% & 68 \% \\ \text { Percent where device interrupted } & & & \\ \quad \text { current } & 50 \% & 27 \% \text { (of 11) } & 33 \% \text { (of 15) } \\ \text { (One case, not shown above, had no overcurrent protection device.) } & \\ \text { Lighting Fixtures } & & \end{array}$

Percent of fires

7
$50 \%$

Percent with tampering

Percent with unusual panel conditlons

Percent with system alterations

Percent where device interrupted current

\section{$100 \%$}

$100 \%$

$71 \%$

$0 \%$ (of 5)
7
$50 \%$

$0 \%$

$29 \%$

$57 \%$

$29 \%$
14

$100 \%$

$50 \%$

$64 \%$

$64 \%$
27

$100 \%$

$30 \%$ (of 23)

$46 \%$ (of 26)

$67 \%$

$42 \%$ (of 24 ) 
Table 20. Wire Size and Overcurrent Protection Device Rating by Type of Device

(Smallest AWG size in circult)

\section{AWG Wire Size}

\begin{tabular}{|c|c|c|c|c|c|c|c|}
\hline Edison & Base Fuses & $\underline{6}$ & 8 & 10 & 12 & 14 & $16 / 18^{*}$ \\
\hline $15 \mathrm{amp}$ & & 0 & 0 & 0 & 1 & 1 & 0 \\
\hline 20 amp & & 0 & 0 & 0 & 1 & 7 & 0 \\
\hline $25 \mathrm{amp}$ & & 0 & 0 & 0 & 2 & 4 & 0 \\
\hline 30 amp & & 0 & 0 & 0 & 2 & 18 & 1 \\
\hline $40 \mathrm{amp}$ & & 0 & 0 & 0 & 0 & 0 & 0 \\
\hline 50 amp & & 0 & 0 & 0 & 0 & 0 & 0 \\
\hline & Total & $\overline{0}$ & $\overline{0}$ & $\overline{0}$ & $\overline{6}$ & $\overline{30}$ & $\bar{I}$ \\
\hline
\end{tabular}

Circult Breakers

$15 \mathrm{amp}$

20 amp

25 amp

30 amp

40 amp

50 amp

Total

Combined Data

15 amp

20 amp

25 amp

30 amp

40 amp

50 amp

Total

$\begin{array}{ll}0 & 0 \\ 0 & 0 \\ 0 & 0 \\ 0 & 1 \\ 0 & 1 \\ \frac{2}{2} & \frac{0}{2}\end{array}$

0
1
0
0
0
$\frac{0}{1}$

$\begin{array}{r}5 \\ 12 \\ 0 \\ 0 \\ 0 \\ 0 \\ \hline 17\end{array}$

$\begin{array}{rl}26 & 0 \\ 2 & 1 \\ 0 & 0 \\ 0 & 0 \\ 0 & 0 \\ 0 & . \\ 28 & \frac{0}{1}\end{array}$

0
1
0
0
0
$\frac{0}{1}$

Note: These figures exclude the service component cases. Also excluded are one case where the type of device was unknown, one Edison-base fuse case where the rating of the fuse was unknown, and 2 circuit breaker cases where the wire sizes were unknown.

* These cases, where smaller wiring than normal was found within branch circuits, had power cord/lamp cord spliced directly into the involved branch circuit. 
Table 21. Overcurrent Protection Device Performance by Type and Rating of Device and Wire Size -

Percentage of Cases Where Device Interrupted Current

(Smallest AWG size in circuit)

Fuses

$15 \mathrm{amp}$

20 amp

$25 \mathrm{amp}$

$30 \mathrm{amp}$

40 amp

50 ainp

Circuit Breakers

$15 \mathrm{amp}$

$20 \mathrm{amp}$

25 amp

$30 \mathrm{amp}$

$40 \mathrm{amp}$

$50 \mathrm{amp}$

Combined

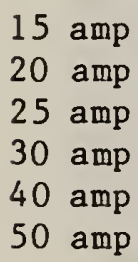

$15 \mathrm{amp}$

20 amp

$25 \mathrm{amp}$

30 amp

$50 \mathrm{amp}$

* No such cases

Note: Excluded from thts table are all the cases excluded from table 20 and all cases where either the fire caused the device to operate or it was unknown whether the device operated.

\section{AWG WLre Size}

$\underline{6 / 8 / 10} \quad \underline{12} \quad \underline{14} \quad \underline{16 / 18}$

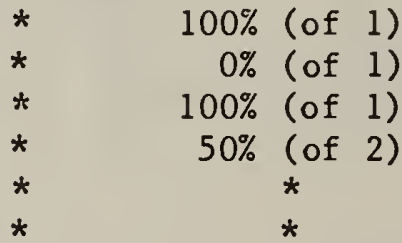

$0 \%$ (of 1)

$67 \%$ (of 6 )

$33 \%$ (of 3 )

$40 \%$ (of 15)

$0 \%($ of 1$)$

*
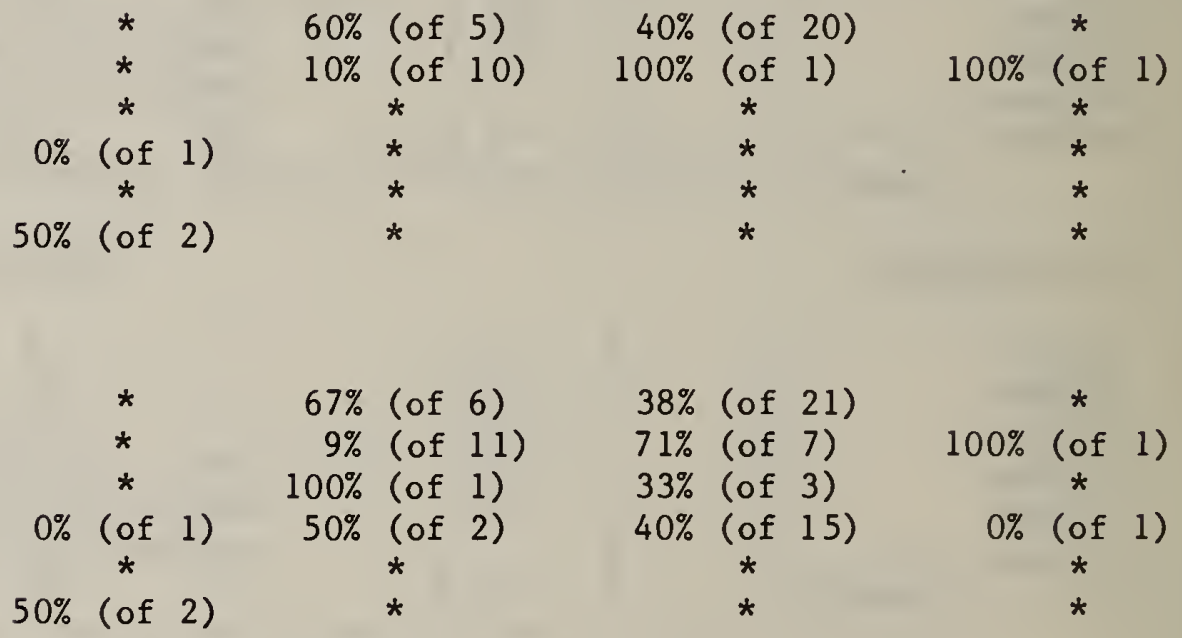
Older buildings accounted for a disproportionately large share of the fires examined, but building age was highly correlated with several other factors, and so there is no clear indication of which factor(s) was the leading element in raising the risk of electrical distribution fire. Table 22 shows the increase in fire rate as building age increased. The fire rate for housing constructed in the 1950's is about equal to the fire rate for all housing which is nearly three times the fire rate for housing built in the 1960's and 1970's and just over half the fire rate for housing built before 1940 .

Table 22. Ratio of Electrical Fires to Housing Units by Age of Housing

\begin{tabular}{|c|c|c|c|c|}
\hline $\begin{array}{c}\text { Year of } \\
\text { Construction } \\
\end{array}$ & $\begin{array}{l}\text { Age of } \\
\text { Housing } \\
\text { in } 1980 \\
\end{array}$ & $\begin{array}{l}\text { Est imated Percentage } \\
\text { of All Housing Units } \\
\text { with that Age } \\
\end{array}$ & $\begin{array}{l}\text { Percentage of }{ }^{b} \\
\text { Fires in Housing } \\
\text { of that Age } \\
\end{array}$ & $\begin{array}{l}\text { Index-Ratio } \\
\text { of Fires to } \\
\text { Housing Units }\end{array}$ \\
\hline $\begin{array}{r}1970-79 \\
1960-69 \\
1950-59 \\
1940-49 \\
\text { Pre-1940 }\end{array}$ & $\begin{array}{r}1-10 \text { yrs } \\
11-20 \text { yrs } \\
21-30 \text { yrs } \\
31-40 \text { yrs } \\
\text { Over } 40 \text { yrs } \\
\text { Total }\end{array}$ & $\begin{array}{l}21.8 \\
21.5 \\
14.7 \\
11.0 \\
31.0 \\
100.0\end{array}$ & $\begin{array}{r}8.6 \\
6.7 \\
14.3 \\
14.3 \\
56.2 \\
100.0\end{array}$ & $\begin{array}{l}0.39 \\
0.31 \\
0.97 \\
1.30 \\
\frac{1.81}{1.0}\end{array}$ \\
\hline
\end{tabular}

a The percentage distribution for housing units built before 1970 is based on Census figures for housing units in the citles used in the study, $i . e .$, of all housing built before 1970 in those cities, $27.4 \%$ was built in 1960-69, $18.9 \%$ in $1950-59,14.1 \%$ in $1940-49$, and $39.6 \%$ before 1940 . Because similar figures for those particular cities were not avallable for the period of 1970-79, the national Census figure of $21.8 \%$ was used, and then the study cities' distribution of pre-1970 housing units was pro-rated over the $78.2 \%$ of all housing built before 1970. A check of national figures for pre-1970 periods suggest the cltles' distribution is not significantly different from the national distribution [2].

b Based on 105 study fires. This total excludes four fires where building age was not recorded and the only fire in Oakland. The latter was excluded on the theory that it would not be appropriate to include all the housing units in Oakland in the building-age just to accommodate one fire.

c The Index indicates how much higher or lower than the overall fire rate was the fire rate for a particular bullding-age cohort. 


\subsection{Edison-Base Fuses and Circuit Breakers by Age of Building}

Fuses were phased out of most housing after 1950, so the use of fuses versus circuit breakers is correlated with building age. Of the 31 fires in buildings built between 1950 and 1980, 25 buildings (81\%) had circuit breakers while only 4 (13\%) had Edison-base fuses, and no building built after 1959 had fuses. One had a type $S$ fuse, and the type of device was unknown in the remaining one. By contrast, of the 74 fires in buildings built before 1950, $33(45 \%)$ had Edison-base fuses, 27 (36\%) had circuit breakers. A total of 13 had power company fuses only, and one had no device. Thus, the housing stock of the pre-1950 period shows slightly greater presence of fuses than circuit breakers, while the housing stock of post 1950 shows fuses to be a minor factor.

The problem noted earlier involving failures of untampered circuit breakers to interrupt the current was slightly more prevalent in older housing. In 7 of the 22 fires (32\%) involving untampered circuit breakers in housing built in or after 1950, the current was interrupted by the circuit breakers. Correspondingly, in 5 of the 22 fires (24\%) involving untampered circuit breakers in housing built before 1950, the circuit breakers acted to interrupt the current. (Included in the base are 7 cases where 1 was not determined whether the circuit breaker had operated and 2 cases where the fire, rather than the electrical failure, caused the circuit breaker to operate. These 9 cases split fairly evenly, 5 before 1950 and 4 after.)

Tampering with the overcurrent protection device is correlated with building age primarily because use of fuses is correlated with building age, as figure 2 demonstrates. Of the 29 fires in buildings built in 1950 or after and having Edison-base fuses or circuit breakers, 3 of the 4 buildings with fuses were tampered with, whlle only 1 of the 25 buildings with circuit breakers were tampered with. This gives an overall tampering rate of at least $14 \%$ ( 4 out of 29). (The qualification "at least" is needed because in two circult breaker cases the report did not indicate whether tampering had occurred.) of the 60 fires in bulldings bullt before 1950 and having Edisonbase fuses or circuit breakers, 27 of the 33 with fuses were tampered with while only 4 of the 27 with circuit breakers were tampered with, producing an 


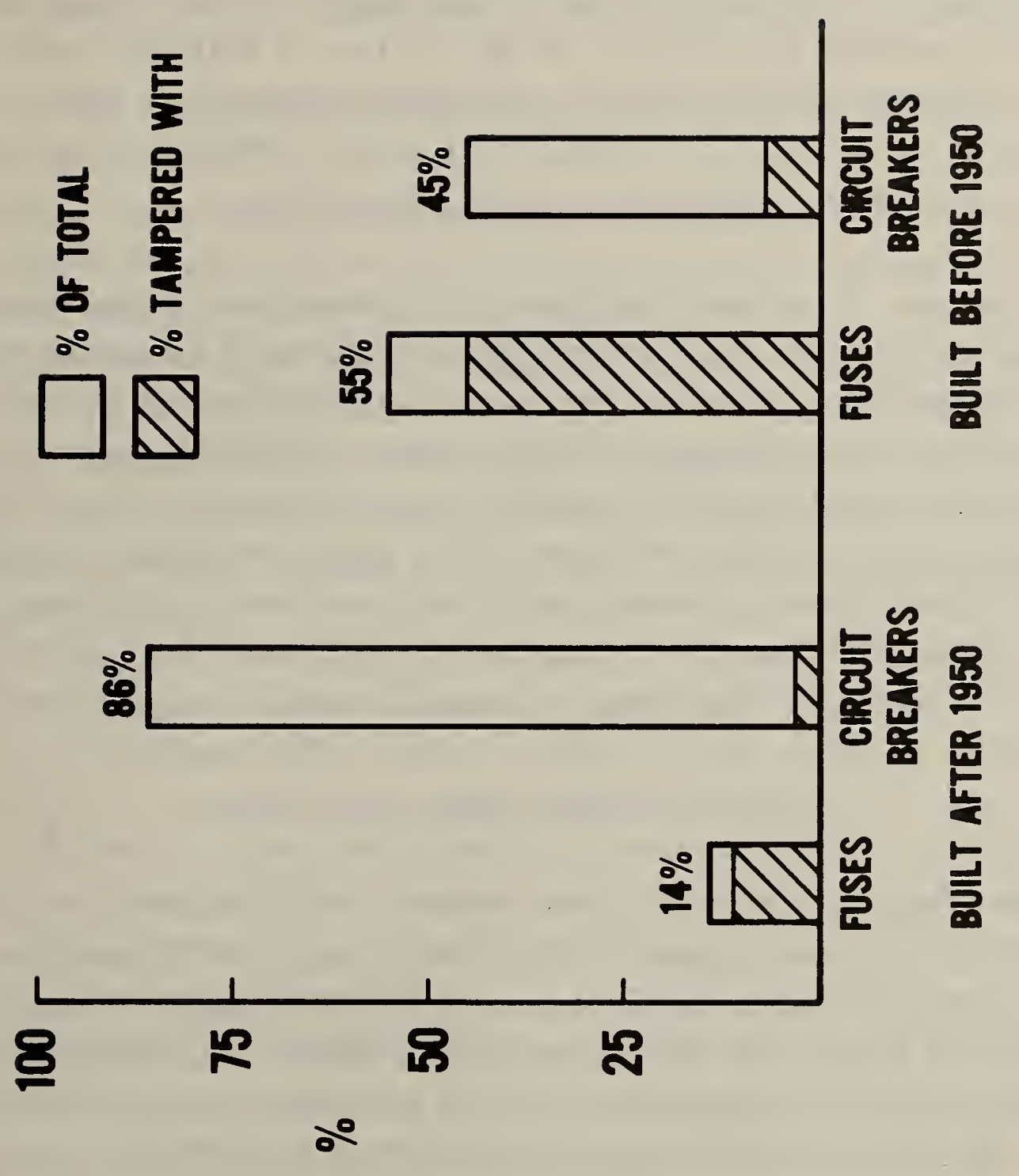

ป 
overall tampering rate of at least 52\% (31 out of 60). (Again, the result is qualified because in 4 fuse cases and 1 circuit breaker case it was not determined whether tampering had occurred.)

Interestingly, many of the tampered fuses worked anyway, and this was somewhat truer for older buildings than for newer ones. Of the 11 fires in buildings built in 1940 or after and having tampered fuses, 3 fuses worked anyway for a success rate of $27 \%$. Of the 10 fires in buildings bullt in the $1930^{\prime}$ s and having tampered fuses, 5 fuses worked anyway for a success rate of $50 \%$. And of the 9 fires in buildings built before 1930 and having tampered fuses, 4 fuses worked anyway for a success rate of $44 \%$.

The pattern for unusual conditions (overfusing, poor workmanship, double taps, bootleg circuits, etc.) found at the panel closely paralleled the pattern for tampering; both were correlated with building age primarily because the most common unusual condition found, overfusing, is more common for fuses than circuit breakers and fuses are more common in older buildings. Of the 29 fires in bulldings built in 1950 or after and having Edison-base fuses or circuit breakers, unusual conditions were found at the panel in 3 of the 4 buildings with fuses, while they were noted in only 5 of the 25 cases with circuit breakers. This gives an overall unusual conditions rate of at least $28 \%$ for buildings built in 1950 or later. (This qualification is needed because in one of the circuit breaker cases, it was unknown if unusual conditions existed.) of the 60 fires in bulldings built prior to 1950 and having Edison-base fuses or circuit breakers, unusual conditions were found in 30 of the 33 cases with fuses compared to 8 of the 27 with circuit breakers. This gives an overall unusual conditions rate of at least $63 \%$ for buildings built prior to 1950, again, most likely due to the frequency of overfusing found. (The qualification is needed because in one fuse case and one circuit breaker case, it was unknown whether unusual conditions were present.)

\subsection{System Alterations by Age of Building}

As expected, system alterations were rare in newer buildings, common in somewhat older buildings, and almost universal in very old buildings. Of the 16 buildings built in the $1960^{\prime}$ s and $1970^{\prime} s$, only 5 (31\%) had had altera- 
tions. Of the 55 buildings built in the 1930's, 1940's, 1950's, however, 38 buildings (69\%) had had alterations. And of the 34 buildings built prior to 1930,32 (94\%) had had alterations. The significance of this pattern is unclear, however, because, as noted earlier, overcurrent protection devices both fuses and clrcuit breakers - were more likely to operate in properties that had had alterations then in those that had not, and, as noted in section 4.2 , the relevance of the alterations to the fire has not yet been determined.

\subsection{Components Involved in Ignition by Age of Bullding}

Table 23 shows how the involvement of different major classes of components differs for pre-1940 and post-1940 housing. The most notable pattern is for service equipment, which has a much larger share of its fires in older housing than do the other component groups. At the other extreme, branch circuit wiring and switches and receptacles show the smallest differences in fire rates between old and new buildings. (These figures may conceal an age dependency for branch circuit wiring, however.) Ninety-three percent of these fires occur in housing 20 years old or older. If the cutoff for checking age effects had been made at 20 years rather than 40 years, the picture for branch circult wiring would have been much different. This will be further evaluated for the final report, and correlated with system age if possible.

\subsection{Wiring Method by Age of Building}

Table 24 presents the distribution of wiring method by age of building as given in the cases, and type of overcurrent protection device; the figures exclude service component fires and the single low voltage transformer fire. Nonmetallic sheathed cable was present in most of the fires in buildings constructed in or after 1950 and is nearly as common in fires in buildings constructed before 1950 as the leading wiring method, knob and tube. Circuit breakers were used primarily with nonmetallic sheathed cable, while fuses were used with nonmetallic sheathed cable and knob and tube wiring. When electric metallic tubing was used, it was solely with circuit breakers, and when armored cable was used, it was usually with fuses. The "other" category in table 24 is primarily made up of hybrid wiring systems, that is a mix of multiple wiring methods within the individual system. 
Table 23. Ratios of Fire Rates for Post-1940 and Pre-1940

Housing by Type of Component Involved in Ignition

Type of
Component
Involved in
Ignition

Housing Units Built in 1940 or After

\begin{tabular}{cc}
$\begin{array}{c}\text { Number of } \\
\text { Fires }\end{array}$ Percent of \\
\hline
\end{tabular}

3

$21 \%$

Equipment

Branch

Circuit

Wiring

Cords and

Plugs

Switches and

Receptacles

Lighting

Fixtures

All

Components

16

$53 \%$

$37 \%$

$55 \%$

$46 \%$

\begin{tabular}{l} 
Housing Units Built \\
Before 1940 \\
$\begin{array}{c}\text { Number of } \\
\text { Pires }\end{array}$ \\
\hline
\end{tabular}

Ratio of Fire Rate for Pre-1940 Housing Units to Fire Rate for Post-1940 Housing Units ${ }^{a}$
11

$79 \%$

8.4

7

$54 \%$

2.6

$59^{\mathrm{b}}$

$56.2 \%$

2.9

a This is given by the ratio of the prior to 1940 and after 1940 percentages, divided by .449 , which is the ratio of housing units built prior to $(31.0 \%)$ and after $1940(69.0 \%)$, as noted in table 22 .

b The total includes one low-voltage transformer case, which does not fit with any of the major component groups. 
Table 24. Wiring Method by Building Age and Type of Overcurrent Protection Device

(Excluding fires in service components or low voltage transformers)

A. All Fires

\begin{tabular}{|c|c|c|c|c|}
\hline Wiring Method & Circuit Breakers & $\begin{array}{c}\text { Edison Base } \\
\text { Fuses } \\
\end{array}$ & Other/Unknown & Total \\
\hline allic sheathed & & & & \\
\hline le & $60 \%$ & $32 \%$ & $33 \%$ & $48 \%$ \\
\hline and Tube & $11 \%$ & $45 \%$ & $33 \%$ & $26 \%$ \\
\hline tric Metallic Tubing & $11 \%$ & $0 \%$ & $0 \%$ & $6 \%$ \\
\hline red Cable & $2 \%$ & $13 \%$ & $0 \%$ & $6 \%$ \\
\hline & $15 \%$ & $11 \%$ & $33 \%$ & $14 \%$ \\
\hline Total & $\overline{100 \%}$ & $100 \%$ & $100 \%$ & $100 \%$ \\
\hline Number of Fires & 53 & 38 & 3 & 94 \\
\hline
\end{tabular}

(These totals include 4 fires not included below - 3 with age unknown and the one fire from Oakland, which is not included in any distribution by age for reasons given earlier.)

B. Fires in Housing Built Prior to 1950

\begin{tabular}{|c|c|c|c|c|c|}
\hline Wiring Method & Circuit & Breakers & $\begin{array}{c}\text { Edison Base } \\
\text { Fuses } \\
\end{array}$ & Other/Unknown & Tota 1 \\
\hline
\end{tabular}

Nonmetallic sheathed cable

Knob and Tube

Electric Metallic Tubing

Armored Cable

Other

Total

Number of Fires

\begin{tabular}{r}
$41 \%$ \\
$22 \%$ \\
$15 \%$ \\
$4 \%$ \\
$19 \%$ \\
\hline $100 \%$ \\
27
\end{tabular}

\begin{tabular}{r}
$28 \%$ \\
$47 \%$ \\
$0 \%$ \\
$13 \%$ \\
$13 \%$ \\
\hline $100 \%$ \\
32
\end{tabular}

$28 \%$

$47 \%$

$0 \%$

$13 \%$

32

\begin{tabular}{r}
$33 \%$ \\
$33 \%$ \\
$0 \%$ \\
$0 \%$ \\
$33 \%$ \\
\hline $100 \%$ \\
3
\end{tabular}

$34 \%$

$35 \%$

$6 \%$

$8 \%$

$16 \%$

$100 \%$

62

C. Fires in Housing Built in or After 1950

\begin{tabular}{|c|c|c|c|c|c|}
\hline Wiring Method & Circuit & Breakers & $\begin{array}{c}\text { Edison Base } \\
\text { Fuses }\end{array}$ & Other/Unknown & Total \\
\hline
\end{tabular}

Nonmetallic sheathed

cable

Knob and Tube

Electric Metallic Tubing

Armored Cable

Other

Total

Number of Fires

\begin{tabular}{cr}
$88 \%$ & $75 \%$ \\
$0 \%$ & $0 \%$ \\
$8 \%$ & $0 \%$ \\
$0 \%$ & $25 \%$ \\
$4 \%$ & $0 \%$ \\
\hline $100 \%$ & $100 \%$ \\
24 & 4
\end{tabular}

--
--
--
--
--
0

Note: Percentages may not total to $100 \%$ because of rounding error. 


\subsection{Separate Grounding Conductor}

Of the 95 cases not involving system components, 25 (26\%) had separate grounding conductors, while $67(71 \%)$ did not and $3(3 \%)$ were undetermined. This does not necessarily indicate that most circuits were ungrounded. An attempt will be made in the followup effort to evaluate grounding of involved circuits.

\section{THERMAL INSULATION}

Information on thermal insulation, including type (cellulose, mineral, etc.) and age was asked for in the questionnaire. Except for several cases involving cellulose insulation, however, the coding detail was insufficient for further analysis.

Cellulose insulation was noted to be present in 9 cases in this study. of the 7 cellulose insulation cases for which the installation date was known, all had had the insulation installed within 2 years of the fire.

Of the 8 cellulose insulation fires not involving service components, 6 (75\%) involved branch circuit wiring and 2 were light fixture fires. In 4 of the 8 cases mechanical damage or a poor splice or connection was involved. Encapsulation or combustible too close was given as the fallure mode in 3 cases ( 2 involving knob and tube wiring). Most of the fires involving cellulose insulation resulted from an overheat condition rather than from arcing.

Although the data on cellulose insulation are very limited, the need for further evaluation is suggested by this data. An evaluation of the percentage of homes containing cellulose insulation in the subject citles to contrast relative exposure to relative involvement in fires would be useful. The dominant failure mode involving cellulose insulation for the cases available appears to relate to encapsulation and/or proximity of combustible insulation to wiring undergoing an overheat condition. As very little detailed information on the contribution of thermal insulation was coded, a more comprehensive examination of the cases involving all types of thermal insulation will be attempted in the followup. 


\section{SERVICE COMPONENT FIRES}

As noted earlier, the category of service components consists of utility supply conductors, service entrance wiring, service equipment and distribution panels. Service components were cited as the component involved in ignition in 15 cases, or $14 \%$ of the total. As noted in section 5 , service component fires were relatively rare in buildings under 40 years of age. None of the 6 cases involving service entrance wiring occurred in buildings less than 40 years old.

No consistent single failure mode or contributor was noted for service components. A total of 5 fires were attributed to deteriorated insulation, with water accumulation noted in 3 cases. In 4 cases the primary causal factor was given as improper installation of a recently altered system, resulting in a ground fault or overload condition. Alterations in progress were responsible for 2 additional fires, one resulting from accidental contact with high voltage lines, and one from the removal of support for the service entrance cable. Finally, 4 cases were essentially unknown, including 2 ground faults from unspecified failures.

\section{BRANCH CIRCUIT WIRING FIRES}

Several aspects of fires involving branch circuit wiring have been discussed in earlier sections. Several additional tabulations are discussed here.

A total of $68 \%$ of the involved branch circuits contained at least some \#14 AWG wire. This is consistent with the wire size distribution across all cases 1 isted in table 14. A separate grounding conductor was present in $22 \%$ of the branch circuit cases, slightly less than the overall $28 \%$.

Most of the involved branch circuits were 120 volt (91\%) and $75 \%$ were general purpose (lighting and receptacle) circuits. The remainder were divided equally between small and large appliance circuits. 
In 12 cases ( $38 \%$ ) one or more electrical components supplied by the involved circuit were noted to be "on" at the time of the fire. In 6 cases (19\%) it was indicated that no electrical components were "on" at ignition, and the remaining 14 cases ( $44 \%$ ) were unknown. The connected circuit load on the involved branch circuit was not known in $53 \%$ of the cases. In the 9 cases where a connected circuit load was provided, it ranged from 3 watts to 2,160 watts.

Overloading of the circuit was unknown in 9 of the cases. Of the remaining 23 cases, $7(30 \%)$ were noted to be overloaded. All of the involved branch circuits had been damaged electrically, damaged by the fire, or both. In addition, 7 were found to have been damaged mechanically, 2 were corroded and one had multiple types of damage noted.

Finally, of the specific component failures causing the fire, mechanical damage (most often by staples) and splice problems stand out.

\section{CORD AND PLUG FIRES}

of the 28 fires involving cords and plugs, 16 (57\%) involved extension cords, 5 were permanently attached appliance cords, 5 were detachable appliance cords and 2 were Christmas tree light cords.

As indicated in section 5.3, cord and plug fires occurred more of ten in older buildings than did any other non-service component fires. This may be largely due to the use of extension cords to extend outmoded, inadequate or defectlve branch circuit wiring in older buildings. This hypothesis is supported by the fact that a cube tap or other device was used to extend the wiring of the building in 54\% of the cases. Also in all 16 extension cord cases, the cords were noted to be replacing permanent bullding wiring.

The involved cord was plugged into a grounded receptacle in only 6 cases, 4 of which were in buildings less than 15 years old. All of the ungrounded receptacles were in buildings over 25 years of age, and $81 \%$ were in buildings over 40 years old. 
Since the dominant problem in cords and plugs appears to be the use of extension cords to replace building wiring, the remaining analysis in this section focuses on them. The misused extension cords were also heavily used, compounding the problem. of the 16 extension cords, 8 were being used daily, 24 hours per day; and another one was used daily 8 hours per day. A total of 3 were used daily, 3 hours per day; 1 was used dally, 2 hours per day; and one was used about one hour per month; one had just been put into use; and one was used daily for an unknown time. This pattern of extensive operation contrasted with the pattern for appliance cords, where only 3 of 10 were in use 24 hours per day. In any event, appliance cords are of ten designed to stand up to heavy use.

One-half of the appliance cord fallures were at the plug, while only 1 of the 16 extension cord fallures occurred at the plug, possibly indicating that the weak link in extension cords is the cord itself. A total of 10 of the 16 extension cords were noted as lamp cord, while 8 of the 10 cords used with appliances were noted to be the generally heavier duty appliance or power cords.

While all of the 7 appliance cords where cord age was known were over 7 years old, only 2 of the 12 extension cords of known age were over 7 years old. The remaining 10 were under 5 years old, and 4 were one year old or less. This indicates that, unlike appliance cords, the effect of age in extension cords may be a secondary issue relative to the issue of use, and misuse, of the cords.

Except for the predominance of plugs and older cords, there was no clear pattern of specific failure mode for appliance cords. A clear pattern of misuse of extension cords is indicated, however. The specific failure mode was given as mechanical damage in $44 \%$ of the cases, overloading in $44 \%$ of the cases, and splicing in the remaining $12 \%$. Although splicing was indicated as the specific fallure mode in only 2 cases, 8 of the 16 extension cords had been spliced (versus only 1 of the 10 appliance cords). The frequency of overloading fires is most likely explained by the use of the cords to replace or extend building wiring. The mechanical damage problem may be in part explained by cord location, as in 14 of the 15 cases where location was known, 
the extension cord was noted to be improperly located, of ten in multiple ways. A summary of the ways in which extension cords were improperly located is given in table 25 .

Table 25. Details of Improper Location of Extension Cords (Improper location noted in $93 \%$ of cases where location was known)

Nature of Improper Location

Frequency Noted

On floor in traffic areas 7

At tached to building surfaces with nails, staples

5

Through doorways, windows, etc.

Wrapped around objects

4

Through holes in walls, floors

3

Close to heaters, hot objects

NOTE: Some cords had more than one feature of improper location. The 22 location problems correspond to 14 cases.

Misuse of extension cords was responsible for most of cord and plug fires in this data base. While such misuse is difficult to address, a more detailed examination of extension cord failure modes will be attempted in the followup, to determine possible alternatives, such as individually fused cords, a larger wire size or improved insulation, which might minimize problems resulting from overloading and some kinds of mechanical damage.

\section{SWITCHES, OUTLETS AND RECEPTACLE}

Fires in receptacles were more evenly distributed over bullding age than fires in any other component involved in ignition, and this fact correlated with a higher than usual percentage of fires occurring in homes with circuit breakers. Splices and connections were notable as problems, suggesting that loose connections between the receptacles and the wirlng played a leading role in ignition, and there was a notably low proportion of ungrounded receptacles. 
11.1 Age of Building and Overcurrent Protection Devices

As noted in section 5, receptacle fires are much less concentrated among older buildings than are other fires. For all fires, the fire rate in pre1950 buildings is nearly three times the fire rate in post-1950 buildings, but for receptacles the fire rate in pre-1950 buildings is less than twice as great. Buildings built in or after 1960 account for $30 \%$ of receptacle fires but only $12 \%$ of all other fires. This suggests that, relative to other parts of the electrical system, receptacles have a larger share of problems that are there from the beginning, as contrasted with problems that show up only after the passage of decades.

Since fuses were largely phased out after 1950, the use of circuit breakers is correlated with building age, and so receptacle fires show a significantly higher percentage of cases with circuit breakers present. Receptacles were protected by circuit breakers in $75 \%$ of the cases versus $20 \%$ by Edison fuses and $5 \%$ (one case) with no device. This compares with $51 \%$ circult breakers, $46 \%$ Edison fuses and 3\% other devices in all other cases not involving system components or low voltage transformers.

\subsection{Problems with Splices and Connections}

Receptacle fires accounted for a major share of fires at splices and connections. For receptacle fires, $55 \%$ were at splices or connections, compared to $38 \%$ of all other fires, excluding fires involving system components or low voltage transformers, where only $19 \%$ of fires were at splices or connections.

If this pattern of fires at splices and connections suggests a pervasive problen with loose connections, the specifics of components whose failure caused the fire strengthen that suggestion. Six of the 11 fires at splices or connections (10 of which were copper wiring) definitely involved loose connections. Three others had the component causing the fire listed as unknown or uncertain. The other two consisted of one case with an old, deteriorated outlet and one case with poorly installed aluminum wiring. 
of particular interest is the pattern for the 4 fires involving backwired receptacles. First, there is the fact that 4 back-wired receptacle cases appear to represent a larger than expected proportion of the 19 receptacle cases where $L t$ was known how the receptacle was wired. Second, 2 of those 4 cases definitely involved a loose connection, and a third involved a fire at a splice or connection where the component causing the fire was uncertain.

\subsection{Grounding}

Of the 17 receptacle fires where it was known whether the receptacle was grounded, 8 were grounded $(47 \%)$ and 9 were not. The 8 that were grounded consisted of 4 with the grounding conductor going directly to the receptacle, one each with the conductor gotng to an isolated screw in the outlet box or a grounding clip, and 2 involving some other arrangement.

Grounding was far more prevalent in newer buildings. In the 8 buildings built in or after $1950,5(63 \%)$ had grounded receptacles - and it was $67 \%$ for buildings built in or after 1960 - while only 3 of the 9 buildings built prior to 1950 (33\%) had receptacle grounding. (These calculations exclude the three cases where it was unknown whether the receptacle was grounded.)

There were 12 cases Involving metal outlet boxes where it was known whether the box was grounded; it was not grounded in $67 \%$ of those cases. The relationship to age was even more pronounced here. Of the 4 buildings built in or after $1950,3(75 \%)$ had grounded outlet boxes, while only 1 of the 8 pre-1950 buildings (13\%) did.

\subsection{Other Factors}

Several elements that had been considered likely to emerge as factors in receptacle fires did not. Only one of the fires involved a receptacle located near a heating unit and only one involved a receptacle surrounded by thermal insulation. 
Recent alterations, replacements, rewiring or installation were less often cited in receptacle ftres ( 2 of 19 cases, or $11 \%$ ) than in other fires ( 15 of 70 cases, or $21 \%$ ), excluding service components and low voltage transformers. (These figures also exclude 4 cases where recent changes were unknown and one case with recent fire damage.)

\section{LIGHT FIXTURE, LAMPHOLDER AND PORTABLE LAMP FIRES}

Of the 14 fires involving light fixtures, lampholders and portable lamps, 13 involved incandescent lights, and only one involved a fluorescent fixture. The fallure of the fluorescent fixture was due to the ballast being installed too close to combustible material. Three of the remaining incandescent light fires also were not electrical in nature, as 2 were caused by the tgnition of combustible material draped over lighted portable lamps, and the third was the ignition of a home-made macrame fixture due to over-heating. Of the remaining 10 fires, one resulted from a loose cord connection in a portable lamp and the other 9 involved light fixtures permanently connected to building wiring.

Of these last 9 fires, 3 were caused by overlamping of the light fixture, and one related to the encapsulation of a light fixture by cellulose insulation. Two cases involved porcelatn lampholders - one caused by deteriorated insulation and the other by a loose connection - and one case was a juryrigged metal and plastic fixture attached to the building wiring by lamp cord with taped splices. The remaining 2 fixtures were permanently connected, and the failure mode was indicated as a loose splice in one and in the other an improper crimp in the supply to the fixture which energized the fixture, lgniting insulation. Of the last 5 cases (all electrical failures in permanently connected fixtures) 2 had been recently worked on, one had not, and the other 2 were undetermined.

\section{CONCLUSIONS}

This initial analysis of 110 electrical fires has produced a number of intriguing hypotheses on the factors that cause or exacerbate electrical fires. Some of these hypotheses and subject areas will be the subject of further investigation, either through refined analysis of these 110 cases or through analysis of additional cases. 
Among the hypotheses and areas that will be examined further are:

(1) the factors that cause overcurrent protection devices to fall to operate, particularly explanations for the fallures of untampered circuit breakers;

(2) the role of extension cords misused as permanent extensions of basic wiring as the apparent dominant factor in fires involving cord and plugs; and (3) the problem of loose connections between receptacles and wiring (especially back-wired receptacles), which appears to be the leading fallure mode for receptacle fires.

Additional steps will include an examination of the size of the total national fire problem associated with each of the major electrical components and failure scenarios, using the NFIRS data base. Also, since system alterations are more the rule than the exception, and especially in light of some of the correlations with alterations, the cases will be re-examined with the intent of separating system improvements from system downgrades. A second attempt will be made to establish workable groupings of the numerous component-causing-fire scenarios according to physical similarities, likelihood of activating overcurrent protection devices, and other criteria relevant to this analysis. If further data collection is done, the basic questionnaires will be re-examined to identify questions and answer formats that should be added, dropped, or revised to improve the quality of information obtained on any future cases. Finally, additional information contained in the electricians' reports and summaries of overcurrent protection will be encoded, added to the data files and analyzed.

These are leading examples, and this list of next steps is not intended to be exhaustive. Reader response is encouraged on all aspects of the results so far and the course of the research.

\section{ACKNOWLEDGENENTS}

The authors gratefully acknowledge the substantial contributions of Mr. Richard Bukowski, Center for Fire Research, who has provided his electrical engineering expertise to both the review of cases and to the analysis of case data. The efforts of John Ricketts in the review, clarification and compilation of the cases has been Invaluable to this project, as have the 
advice and suggestions of Linda Smith and Ed Krawiec of the Consumer Products Safety Commission. Finally, the efforts of the numerous fire service and electrical investigators in the cities of Akron, Grand Rapids, Long Beach, Oakland, Portland, Sacremento, San Diego, San Francisco, San Jose and Toledo, who provided the data for this study, are gratefully acknowledged.

\section{REFERENCES}

[1] Uniform Coding for Fire Protection, 1976, NFPA NO. 901, National Fire Protection Assn., Boston, MA 02210, 1976.

[2] Statistical Abstract of the United States: 1980, U.S. Bureau of the Census, December, 1980.

[3] Fire in the United States, Third Edition, Federal Emergency Management Agency, Washington, DC 20472, p. 44. 
NBS. 1144 (REV. 2.8C)

\begin{tabular}{|c|c|c|c|}
\hline $\begin{array}{l}\text { U.S. DEPT. OF COMM. } \\
\text { BIBLIOGRAPHIC DATA } \\
\text { SHEET (See instructions) }\end{array}$ & $\begin{array}{l}\text { 1. PUBLICATION OR } \\
\text { REPORT NO. } \\
\text { NBSIR } 83-2677\end{array}$ & \multicolumn{2}{|c|}{ 2. Performins Organ. Report Nof 3. Publication Date } \\
\hline \multicolumn{4}{|c|}{ 4. TITLE AND SUBTITLE } \\
\hline \multicolumn{4}{|l|}{$\begin{array}{l}\text { 5. AUTHOR(S) } \\
\text { Alan Gomberg and }\end{array}$} \\
\hline \multicolumn{3}{|c|}{$\begin{array}{l}\text { NATIONAL BUREAU OF STANDARDS } \\
\text { DEPARTMENT OF COMMERCE } \\
\text { WASHINGTON, D.C. } 20234\end{array}$} & $\begin{array}{l}\text { 8. Type of Report \& Period Covered } \\
\text { Interim Report }\end{array}$ \\
\hline
\end{tabular}

\section{SPONSORING ORGANIZATION NAME AND COMPLETE ADDRESS (Street. City. State, ZIP)}

Consumer Product Safety Commission

5401 Westbard Ave.

Bethesda, MD 20016

10. SUPPLEMENTARY NOTES

Document describes a computer program; SF-185, FIPS Software Summary, is attached.

11. ABSTRACT (A 200-word or less factual summary of most significant information. If document includes a significant bibliography or literature survey, mention it here)

This interim report describes the progress and conclusions to date on an analysis of electrical fire cases by the Center for Fire Research, National Bureau of Standards for the Consumer Products Safety Commission. The report describes the 110 detailed electrical fire investigation reports from 10 participating cities, and discusses preliminary findings resulting from analysis of the computerized data from those reports. These preliminary findings are being used to guide a follow on effort, to be reported on at a later date, to obtain, encode and analyze additional data from the original 110 cases, in order to better define and describe the most significant failure modes of electrical components and the sequences of events which lead to electrical fire ignition.

12. KEY WORDS (Six to twelve entries; alphabetical order; capitalize only proper names; and separate key words by semicolons) Electrical; electrical fires; fire cause; fire data; ignition.

13. AVAILABILITY

X Unlimited

For Official Distribution. Do Not Release to NTIS

[- Order From Superintendent of Documents, U.S. Government Printing Office, Washington, D.C. 20402.

[X] Order From National Technical Information Service (NTIS), Springfield, VA. 2216I
14. NO. OF PRINTED PAGES

57

15. Price

$\$ 10.00$ 
